\title{
Water-soluble low-molecular- weight cellulose chains radially oriented on gold nanoparticles
}

\section{AUTHOR(S):}

Enomoto-Rogers, Yukiko; Kamitakahara, Hiroshi; Yoshinaga, Arata; Takano, Toshiyuki

\section{CITATION:}

Enomoto-Rogers, Yukiko ...[et al]. Water-soluble low-molecular-weight cellulose chains radially oriented on gold nanoparticles. Cellulose 2011, 18(4): 929-936

\section{ISSUE DATE:}

2011-08

URL:

http://hdl.handle.net/2433/149213

\section{RIGHT:}

The final publication is available at www.springerlink.com; この論文は 出版社版でありません。引用の際には出版社版をご確認ご利用くださ $\omega_{\circ}$; This is not the published version. Please cite only the published version. 


\title{
Water-soluble low-molecular-weight cellulose chains radially oriented on gold nanoparticles
}

Yukiko Enomoto-Rogers, Hiroshi Kamitakahara*, Arata Yoshinaga, and Toshiyuki Takano

Division of Forest and Biomaterials Science, Graduate School of Agriculture, Kyoto University, Kitashirakawa-Oiwake-cho, Sakyo-ku, Kyoto 606-8502, Japan; *Author for correspondence (e-mail: hkamitan@kais.kyoto-u.ac.jp; phone: +81-75-753-6255; fax: $+81-75-753-6300)$

\begin{abstract}
Cellulose chains bearing $N$-lipoyl group at the reducing-end as a sulfide linker, self-assembled on the surface of gold nanoparticles (CELL2Au, CELL13Au, and CELL41Au with the number average degrees of polymerization $\left(\mathrm{DP}_{\mathrm{n}}\right)$ of 2,13 , and 41 , respectively) were prepared. CELL2Au, CELL13Au, and CELL41Au were obtained via deprotection of the cellulose triacetate (CTA) self-assembled on the surface of gold nanoparticles that are consisting of CTA chains with corresponding $\mathrm{DP}_{\mathrm{n}}$ organized in a radial manner with head-to-tail orientation, where a head is the reducing-end, and a tail is the non-reducing-end. CELL2Au and CELL13Au were well-dispersed in water including a trace of methanol, whereas CELL41Au was not. The transmission electron microscopy (TEM) observation of CELLAus deposited on copper grids revealed that the diameters $(d)$ of the gold cores of CELL2Au, CELL13Au, and CELL41Au were 6.1, 6.1, and $11.5 \mathrm{~nm}$, respectively. Wide angle X-ray diffractgram showed that cellulose chains of CELL13Au had quite low crystallinity and exhibited additional faint diffraction pattern of cellulose II. Cellulose chains of CELL41Au were amorphous. The UV-vis measurements revealed that CELL2Au and CELL13Au were well-dispersed in water. The hydrodynamic diameters $(D)$ of CELL2Au and CELL13Au in water were 21.8 and $55.9 \mathrm{~nm}$, respectively, according to dynamic light scattering (DLS) measurements, suggesting that cellulose chains on the gold were organized in a radial manner with head-to-tail orientation. ${ }^{1} \mathrm{H}-\mathrm{NMR}$ measurement revealed that low-molecular-weight cellulose chains $\left(\mathrm{DP}_{\mathrm{n}}=13\right)$ on the gold dissolved in water, whereas low-molecular-weight cellulose $\left(\mathrm{DP}_{\mathrm{n}}=13\right)$ itself did not.
\end{abstract}

Key Words: low-molecular-weight cellulose; reducing-end; radial orientation; water-soluble; gold nanoparticles.

\section{Introduction}

Cellulose molecule has a hemiacetalic hydroxyl group at the reducing-end, which has different reactivity from other hydroxyl groups at C2, C3, and C6 positions. Focusing on the specific reactivity of the reducing-end, we have succeeded to prepare cellulosic diblock 
copolymers by introducing long-chain alkyl groups into the reducing-end of cellulose chain (Kamitakahara et al. 2005; Kamitakahara and Nakatsubo 2005). Based on our synthetic strategy, we have studied the orientation and nano-structure of cellulose chains led by introduction of functional groups into their reducing-end. For example, we have recently prepared amphiphilic cellulose derivatives carrying hydrophobic alkyl group and pyrene group at the reducing-end, and have investigated self-assemble properties in $\mathrm{NaOH}$ aqueous solution (Enomoto et al. 2006). We have also prepared copolymers with cellulose side-chains (Enomoto-Rogers et al. 2009a; Enomoto-Rogers et al. 2009b). However, orientation or crystalline properties of cellulose chains in these cellulosic materials have not been investigated yet.

As a method to control the orientation of cellulose chains by immobilization of the reducing-end of cellulose, we have recently prepared cellulose triacetate (CTA) bearing a single disulfide group at the reducing-end, and succeeded in preparation of the CTA-self-assembled gold nanoparticles (CTAAu) (Enomoto-Rogers et al. 2010). CTA chains on the surface of gold nanoparticles were radially oriented in a head-to-tail manner, where a head is the reducing-end, and a tail is the non-reducing-end. The cellulose chains on the gold nanoparticles, which were obtained by deprotection of CTAAu, should be organized in a radial manner with head-to-tail orientation. Moreover, interchain distances of cellulosic chains on the gold nanoparticles (Enomoto-Rogers et al. 2010) were longer than crystalline lattice of cellulose I (Sugiyama et al. 1991; Woodcock and Sarko 1980) and cellulose II (Kolpak and Blackwell 1976). Meanwhile, it is well-known that cellulose is insoluble in water due to its crystalline structure formed via inter- and intra-molecular hydrogen bonding (Kamide et al. 1992). Only cello-oligosaccharides with the $\mathrm{DP}_{\mathrm{n}}$ of up to ca. 7 are known to be soluble in water (Kobayashi et al. 1991) or in dimethyl sulfoxide (Isogai and Usuda 1991). To our knowledge, there have been no reports on radially oriented cellulosic materials. We anticipated that crystallinity and solubility of cellulose chains radially oriented on the gold nanoparticles might be different from free cellulose molecules, such as cellulose I or II.

In the present paper, we describe preparation of cellulose chains self-assembled on the surface of gold nanoparticles (CELL2Au, CELL13Au, and CELL41Au, degrees of polymerization $\left(\mathrm{DP}_{\mathrm{n}}\right)$ cellulose of 2,13 , and 41 , respectively) via deprotection of the cellulose triacetate (CTA)-self-assembled gold nanoparticles. Nanostructure and crystallinity of cellulose chains were also analyzed by transmission electron microscopy (TEM) and X-ray diffraction measurements. Water-solubility of cellulose chains on the surface of gold nanoparticles was analyzed in relationship to their degree of polymerization by means of UV-vis, dynamic light scattering (DLS), and NMR measurements are discussed in terms of crystallinity of cellulose chains.

\section{Experimental}


Materials

The gold nanoparticles grafted with cellulose triacetate (CTA) chains with the $\mathrm{DP}_{\mathrm{n}}$ of 2, 13, and 41, were prepared as reported in our previous article (Enomoto-Rogers et al. 2010), and described as CTA2Au, CTA13Au, and CTA41Au, respectively. Cellohexaose was obtained from Seikagaku Cooperation (Tokyo, Japan). Low-molecular-weight cellulose $\left(\mathrm{DP}_{\mathrm{n}}=15\right)$ were prepared from cellulose microcrystalline (CF-11, Whatman) using phospholic acid according to previous articles (Atalla et al. 1984; Isogai and Usuda 1991). Low-molecular-weight cellulose $\left(\mathrm{DP}_{\mathrm{n}}=13\right)$ was prepared by deacetylation of cellulose triacetate $\left(\mathrm{DP}_{\mathrm{n}}=13\right)$. Sodium methoxide and all other reagents were commercially obtained and used without further purification.

Preparation of CELL2Au, CELL13Au, and CELL41Au nanoparticles

To a solution of CTA13Au (30.0 mg) in $20 \%$ methanol/ chloroform $(10.0 \mathrm{ml})$, sodium methoxide $(0.2 \mathrm{ml})$ was added, and stirred for $1 \mathrm{~h}$. The precipitated compounds were collected by centrifugation at $1000 \mathrm{rpm}$ for $3 \mathrm{~min}$ and washed by methanol. After methanol as supernatant was removed by decantation, the never-dried compounds in residual methanol were dissolved in water, and lyophilized, to obtain the dark purple solid, CELL13Au (14.3 $\mathrm{mg}$ ). The same procedures were applied to CTA2Au and CTA41Au to obtain CELL2Au and CELL41 Au, respectively. ${ }^{1} \mathrm{H}-\mathrm{NMR}(\mathrm{CELL13Au})\left(\mathrm{CDCl}_{3}\right): \delta 3.35(\mathrm{~m}, \mathrm{C} 2-\mathrm{H}), 3.4-3.5(\mathrm{~m}$, C3-H, C4-H, C5-H), $3.68\left(\mathrm{dd}, J_{6 \mathrm{a}, 6 \mathrm{~b}}=11.6, J_{5,6}=4.0, \mathrm{C} 6-\mathrm{H}_{\mathrm{a}}\right), 3.83\left(\mathrm{~d}, J_{6 \mathrm{a}, 6 \mathrm{~b}}=10.0, \mathrm{C} 6-\mathrm{H}_{\mathrm{b}}\right)$, $4.38\left(\mathrm{~d}, J_{1,2}=8.0, \mathrm{C} 1-\mathrm{H}\right)$.

\section{FT-IR measurements}

Fourier transform infrared (FT-IR) spectra were recorded on a Shimadzu FTIR-4000 spectrophotometer equipped with an ATR attachment (Durasampl IR II).

TEM analysis

Transmission electron microscopy (TEM) images were collected by a JEOL JEM-1220 system operating at an accelerating voltage of $100 \mathrm{kV}$. Samples were prepared by depositing CELLAu dispersed in water $(0.1 \mathrm{mg} / \mathrm{ml}, 10 \mu \mathrm{l})$ on copper grids that were pre-coated by Formvar (polyvinyl formal). The samples were stained with uranyl diacetate. The sizes of particles were calibrated using Latex Particles $\phi 0.23 \mu \mathrm{m}$ (Ohken Shoji, Japan). TEM images were recorded on Fuji FG films (Fuji Film, Japan). The image data of the films were printed on photographic papers at 6.3 magnifications. The developed images were stored with a general scanner at 300 dpi. TEM images were analyzed using public domain ImageJ 
program (Rasband, W.S., U. S. National Institutes of Health, Bethesda, Maryland, USA, http://rsb.info.nih.gov/ij/, 1997-2009). The diameters $(d)$ of the gold cores were obtained from measurements of at least 100 particles per sample.

X-ray diffraction measurements

X-ray diffraction measurements were carried out with a Rigaku diffractometer Ultima IV. A Nickel-filtered $\mathrm{CuK} \alpha$ radiation was used at $40 \mathrm{kV}$ and $30 \mathrm{~mA}$. Samples were prepared by lyophilization of never-dried CELLAu dispersed in water. Low-molecular-weight cellulose $\left(D_{n}=15\right)$ was used to obtain reflection pattern of cellulose II.

UV-vis measurements

UV-vis spectra were recorded on a JASCO V-560 spectrometer at $25{ }^{\circ} \mathrm{C}$. CELL2Au and CELL13Au dispersed in water $(0.1 \mathrm{mg} / \mathrm{ml})$ were filtered with poly(tetrafluoroethylene) syringe filter (pore size of $0.2 \mu \mathrm{m}$ ) before the measurement.

\section{DLS Measurements}

Hydrodynamic diameters of gold nanoparticles coated by cellulose chains were recorded on dynamic light scattering (DLS) spectrophotometer (ELS-Z2, Photal Otsuka Electronics) equipped with $\mathrm{He}-\mathrm{Ne}$ laser $(\lambda=632.8 \mathrm{~nm})$ at $25{ }^{\circ} \mathrm{C}$. Hydrodynamic diameters were obtained by Cumulant method. Intensity and number size distributions were obtained by Marquardt method (Gulari et al. 1979). CELL2Au and CELL13Au dispersed in water (1 $\mathrm{mg} / \mathrm{ml}$ ) were filtered with hydrophilic PTFE syringe filter (pore size of $0.2 \mu \mathrm{m}$ ) before the measurement.

NMR measurements

${ }^{1} \mathrm{H}-\mathrm{NMR}$ spectra were recorded on a JEOL JNM-A500 FT-NMR (500 MHz) spectrometer in $\mathrm{D}_{2} \mathrm{O}$. Chemical shifts $(\delta)$ and coupling constants $(J)$ are reported in $(\mathrm{ppm})$ and $(\mathrm{Hz})$, respectively. The precipitated CELL13Au obtained after deacetylation of CTA13Au was collected by centrifugation at $1000 \mathrm{rpm}$ for $3 \mathrm{~min}$ and washed by methanol- $d_{4}$. After methanol as supernatant was removed by decantation, the never-dried CELL13Au in residual methanol was dissolved in $\mathrm{D}_{2} \mathrm{O}$.

\section{Results and Discussion}

Preparation of cellulose chains self-assembled on the surface of gold nanoparticles 
CTA-self-assembled gold nanoparticles, CTA2Au, CTA13Au, and CTA41Au, were treated with sodium methoxide, resulting in the formation of cellulose chains self-assembled on the surface of gold nanoparticles, CELL2Au CELL13Au, and CELL41Au, respectively, as described in Figure 1. Sodium methoxide was chosen as a reagent for deacetylation because no peak was observed in the X-ray diffractograms of the deacetylated compounds when 1,8-diazabicyclo[5,4,0]-7-undecene (DBU) was used (data not shown). The completion of deacetylation was confirmed by FT-IR spectra, as shown in Figure 2. An absorbance of carbonyl $(\mathrm{C}=\mathrm{O})$ group at $1760 \mathrm{~cm}^{-1}$ completely disappeared for CTA13Au, and a strong $\mathrm{OH}$ absorbance at $v=3342 \mathrm{~cm}^{-1}$ appeared for CELL13Au, indicating that deacetylation proceeded completely, and that cellulose chains remained on the gold nanoparticles. Interestingly never-dried CELL2Au and CELL13Au nanoparticles, which are in residual methanol after workup procedures, were well-dispersed in water at least for a week, whereas CELL41Au nanoparticles were not.

\section{TEM observations}

The CELLAu nanoparticles in dry state were analyzed by transmission electron microscopy (TEM). Specimens for TEM observation were prepared by depositing CELLAu nanoparticles dispersed in water on Formvar-pre-coated copper grids. The TEM images of gold nanoparticles, and the size distributions of the diameters $(d)$, are shown in Figure 3. The characteristics of original CTAAu and CELLAu nanoparticles are listed in Table 1. The $d \mathrm{~s}$ of the gold cores of CELL2Au, CELL13Au, and CELL41Au were 6.1, 6.1, and $11.5 \mathrm{~nm}$, respectively. The $d$ s of the gold cores of CTA2Au, CTA13Au, and CTA41Au were 8.7, 7.9, and $13.4 \mathrm{~nm}$, respectively, according to our previous work (Enomoto-Rogers et al. 2010). The $d$ s and its standard deviations showed no substantial difference before and after deacetylation, indicating that the gold nanoparticles were stable under alkaline condition. In the case of CTAAu nanoparticles, the interparticle distance between nanoparticles agreed well with CTA molecular chain length (Enomoto-Rogers et al. 2010). However, in the case of CELLAu nanoparticles prepared in this work, the interparticle distances were irregular and could not be controlled by chain length of cellulose molecule. CELLAu nanoparticles tended to aggregate and it was hard to measure interparticle distances. It is likely due to strong interactions between cellulose chains such as hydrogen bonding. The same phenomenon has been observed in the case of cellulose nanocrystals. Cellulose nanocrystals or particles with free hydroxyl groups formed aggregate in water via Van der Waals interaction or hydrogen bonding (Wang et al. 2008; Wang et al. 2007). Cellulose layer was not observed even when they were stained with uranyl acetate, probably because crystallization of cellulose chains was inhibited by covalent bonding between sulfur atom and gold surface with wider interchain distances compared to crystal lattices of cellulose I or 
cellulose II, as discussed in following section.

X-ray diffraction measurements

In X-ray diffractgrams of CELL13Au and CELL41Au nanoparticles, a strong reflection assigned to Au (111) (Qazi et al. 2009; Wang et al. 2003) were observed, as shown in Figures 4a and 4b. CELL13Au showed the quite weak reflections peaks assigned to cellulose II (110) and (200), as shown in Figures 4a and 4c (Isogai et al. 1989). Regarding the crystalline structure, there are some possibilities for the structures of cellulose chains, because self-assembled structures in solid state could not be investigated in detail. Parallel cellulose chains might show diffraction pattern of cellulose II, or anti-parallel cellulose chains might be formed by interdigitation of cellulose chains on the gold and give diffraction pattern of cellulose II. Therefore, it was hard to discuss the mechanism of formation of cellulose II crystalline structure in relation to the orientation of cellulose chains in self-assembled structures. CELL41Au showed weak amorphous pattern of cellulose as shown in Figures $4 \mathrm{~b}$. According to the contents of CTAS chains in CTAAu calculated in our previous work (Enomoto-Rogers et al. 2010), the contents of cellulose chains in CELL13Au and CELL41Au were calculated to be $14.2 \mathrm{wt} \%$ and $23.3 \mathrm{wt} \%$, respectively as listed in Table 1 . However, crystallinity of cellulose chains on the gold nanoparticles was low. The interchain distances of cellulose chains on the gold surface of CELL13Au and CELL41Au were calculated to be 9.5 and $9.3 \AA$, respectively, according to the our previous work on CTA13Au and CTA41Au (Enomoto-Rogers et al. 2010). Those values were both longer than the interchain distances of cellulose chains in crystal lattice of cellulose $\mathrm{I}_{(}\left(\mathrm{I}_{\alpha}: a=6.74 \AA, b=5.93 \AA, c=10.36 \AA\right.$, $\mathrm{I}_{\beta}: a$ $=8.20 \AA, b=7.78 \AA, c=10.34 \AA$ ) (Sugiyama et al. 1991; Woodcock and Sarko 1980) or cellulose II ( $a=8.01 \AA, b=9.04 \AA, c=10.36 \AA$ ) (Kolpak and Blackwell 1976). The reason for amorphous pattern of cellulose on the surface of gold nanoparticles is likely that crystallization of cellulose chains via hydrogen bonding was inhibited by their covalent grafting on the gold surface at the longer interchain distances than those suitable for the crystallization. This low crystallinity of cellulose chains probably allowed water to interact with hydroxyl groups of cellulose chains, and dispersed CELL13Au in water. Therefore, nano-dispersity and solubility of these amorphous cellulose chains on the surface of gold nanoparticles were investigated in the following sections.

Nanostructures of CELL2Au and CELL13Au in water

The UV-vis spectra and the images of the gold nanoparticles CELL2Au and CELL13Au in water are shown in Figure 5. The absorption band at $\lambda=\mathrm{ca} .530 \mathrm{~nm}$ in UV-vis spectra are assigned to the surface plasmon band of gold (Brust and Kiely 2002), indicating that the gold were well-dispersed in nano-scale. CELL41Au nanoparticles were not dispersed in water, 
probably due to stronger hydrogen bonding between cellulose chains with higher molecular weight.

The hydrodynamic diameters $(D)$ of CELL2Au and CELL13Au nanoparticles in water were determined by DLS measurements, and listed in Table 1. The intensity and number size distributions of CELL2Au and CELL13Au were shown in Figure 6. The hydrodynamic diameter indicates the total diameter of nanoparticles with the gold core and cellulose shell. The hydrodynamic diameters $(D)$ of CTA2Au and CTA13Au in chloroform were 16.6 and $49.0 \mathrm{~nm}$, respectively as discussed in previous work (Enomoto-Rogers et al. 2010). The hydrodynamic diameters $(D)$ of CELL2Au and CELL13Au in water were 21.8 and $55.9 \mathrm{~nm}$, respectively. Generally, in DLS measurement, the larger particles exhibit much stronger intensity even when their number is very small. In the number size distribution, the number of particles around $10 \mathrm{~nm}$ is much larger than that around $100 \mathrm{~nm}$, as shown in Figure $6 \mathrm{~d}$. We consider that the bimodal distribution of intensity is just a result of analysis of scattering data calculated by Marquardt method. Although the solvents are different, the $D$ values showed no substantial difference before and after deacetylation, indicating that the gold nanoparticles were well-dispersed in nano-scale. Consequently, these experiments revealed that the cellulose chains bound covalently on the gold surface in a radial manner.

Solubility of cellulose chains $\left(\mathrm{DP}_{\mathrm{n}}=13\right)$ on the surface of gold nanoparticles in water

Chemical structure of low-molecular-weight cellulose chains $\left(\mathrm{DP}_{\mathrm{n}}=13\right)$ on the gold nanoparticles was analyzed by NMR measurements. ${ }^{1} \mathrm{H}-\mathrm{NMR}$ spectrum of CELL13Au in deuterium oxide $\left(\mathrm{D}_{2} \mathrm{O}\right)$ is shown in Figure 7. The proton resonances appeared at $\delta 4.38(\mathrm{~d}$, $\left.J_{1,2}=8, \mathrm{C} 1-\mathrm{H}\right), 3.83\left(\mathrm{dd}, J_{6 \mathrm{a}, 6 \mathrm{~b}}=12, J_{5,6 \mathrm{a}}=2, \mathrm{C} 6-\mathrm{H}_{\mathrm{a}}\right)$, and $3.68\left(\mathrm{dd}, J_{6 \mathrm{a}, 6 \mathrm{~b}}=12, J_{5,6 \mathrm{~b}}=4\right.$, C6- $\mathrm{H}_{\mathrm{b}}$ ) ppm, although their peak intensities were low. The observed peaks were identical to ring-proton peaks of low-molecular-weight cellulose $\left(\mathrm{DP}_{\mathrm{n}}=15\right)$ in $4 \% \mathrm{NaOD} / \mathrm{D}_{2} \mathrm{O}$ solution (Isogai 1997). It has been reported that mono- or di-saccharides linked on the gold nanoparticles were water-soluble and could be analyzed by ${ }^{1} \mathrm{H}-\mathrm{NMR}$ measurements (de la Fuente et al. 2001; Ojeda et al. 2007). It has also been reported that cellulose with DP of more than ca. 8 are not water-soluble (Kobayashi et al. 1991). The proton peaks of CELL13Au were different from those of cellohexaose $(\mathrm{DP}=6)$, as shown in Figure $7 \mathrm{~b}$. Low-molecular-weight cellulose $\left(\mathrm{DP}_{\mathrm{n}}=13\right)$ itself that was crystallized via inter- and intramolecular hydrogen bonding was insoluble in water. Thus, low-molecular-weight cellulose chains $\left(\mathrm{DP}_{\mathrm{n}}=13\right)$ on the surface of gold nanoparticles were found to "dissolve" in water including a trace of methanol under the neutral condition.

It is likely that crystallization of cellulose chains $\left(\mathrm{DP}_{\mathrm{n}}=13\right)$ via hydrogen bonding was inhibited by covalent bonding of cellulose on the gold nanoparticles with wider interchain distances compared to crystal lattices of cellulose I or cellulose II. Interaction between cellulose chains and water molecules might be accelerated. As a result, the solubility of 
cellulose chains $\left(\mathrm{DP}_{\mathrm{n}}=13\right)$ in water was induced.

\section{Conclusions}

Cellulose chains self-assembled on the surface of gold nanoparticles, CELL2Au, CELL13Au, and CELL41Au were prepared. CELL2Au and CELL13Au were well-dispersed in water with a trace of methanol, while CELL41Au was not. Cellulose chains on the surface of gold nanoparticles were mostly amorphous according to the TEM observation and the XRD measurements. The UV-vis and DLS spectra of CELL2Au and CELL13Au in water revealed that cellulose chains on the gold were organized in a radial manner with head-to-tail orientation. $\quad{ }^{1} \mathrm{H}-\mathrm{NMR}$ measurement revealed that cellulose chains $\left(\mathrm{DP}_{\mathrm{n}}=13\right)$ on the gold nanoparticles dissolved in water. Crystallization of cellulose chains $\left(\mathrm{DP}_{\mathrm{n}}=13\right)$ was inhibited because of their wide interchain distance on the gold surface. As a result, their solubility in water was induced.

\section{Acknowledgements}

We acknowledge Advanced Instrumental Analysis Unit, Graduate School of Agricultural and Life Sciences, the University of Tokyo, for measuring a 500-MHz ${ }^{1} \mathrm{H}-\mathrm{NMR}$ spectrum. This study was supported in part by a Grant-in-Aid from a Research Fellowships of the Japan Society for the Promotion of Science (JSPS) for Young Scientists (Y.E-R), and by a Grant-in-Aid for Scientific Research from the Ministry of Education, Science, and Culture of Japan (Nos. 18688009 and 21580205).

\section{References}

Atalla, R.H., Ellia, J.D. and Schroeder, L.R. (1984) Some effects of elevated temperatures on the structure of cellulose and its transformation. Journal of Wood Chemistry and Technology 4:465-482.

Brust, M. and Kiely, C.J. (2002) Some recent advances in nanostructure preparation from gold and silver particles: A short topical review. Colloids and Surfaces A-Physicochemical and Engineering Aspects 202:175-186.

de la Fuente, J.M., Barrientos, A.G., Rojas, T.C., Rojo, J., Canada, J., Fernandez, A. and Penades, S. (2001) Gold glyconanoparticles as water-soluble polyvalent models to study carbohydrate interactions. Angewandte Chemie-International Edition 40:2257-2261.

Enomoto-Rogers, Y., Kamitakahara, H., Nakayama, K., Takano, T. and Nakatsubo, F. (2009a) Synthesis and thermal properties of poly(methyl methacrylate)-graft-(cellobiosylamine-c15). Cellulose 16:519-530.

Enomoto-Rogers, Y., Kamitakahara, H., Takano, T. and Nakatsubo, F. (2009b) Cellulosic graft 
copolymer: Poly(methyl methacrylate) with cellulose side chains. Biomacromolecules 10:2110-2117.

Enomoto-Rogers, Y., Kamitakahara, H., Yoshinaga, A. and Takano, T. (2010) Radially oriented cellulose triacetate chains on gold nanoparticles. Cellulose 17:923-936.

Enomoto, Y., Kamitakahara, H., Takano, T. and Nakatsubo, F. (2006) Synthesis of diblock copolymers with cellulose derivatives. 3 . Cellulose derivatives carrying a single pyrene group at the reducing-end and fluorescent studies of their self-assembly systems in aqueous naoh solutions. Cellulose 13:437-448.

Gulari, E., Gulari, E., Tsunashima, Y. and Chu, B. (1979) Photon-correlation spectroscopy of particle distributions. Journal of Chemical Physics 70:3965-3972.

Isogai, A. (1997) Nmr analysis of cellulose dissolved in aqueous naoh solutions. Cellulose 4:99-107.

Isogai, A. and Usuda, M. (1991) Preparation of low-molecular-weight celluloses using phosphoric-acid. Mokuzai Gakkaishi 37:339-344.

Isogai, A., Usuda, M., Kato, T., Uryu, T. and Atalla, R.H. (1989) Solid-state cp mas c13 nmr-study of cellulose polymorphs. Macromolecules 22:3168-3172.

Kamide, K., Okajima, K. and Kowsaka, K. (1992) Dissolution of natural cellulose into aqueous alkali solution - role of super-molecular structure of cellulose. Polymer Journal 24:71-86.

Kamitakahara, H., Enomoto, Y., Hasegawa, C. and Nakatsubo, F. (2005) Synthesis of diblock copolymers with cellulose derivatives. 2 . Characterization and thermal properties of cellulose triacetate-block-oligoamide-15. Cellulose 12:527-541.

Kamitakahara, H. and Nakatsubo, F. (2005) Synthesis of diblock copolymers with cellulose derivatives. 1 . Model study with azidoalkyl carboxylic acid and cellobiosylamine derivative. Cellulose 12:209-219.

Kobayashi, S., Kashiwa, K., Kawasaki, T. and Shoda, S. (1991) Novel method for polysaccharide synthesis using an enzyme - the 1st invitro synthesis of cellulose via a nonbiosynthetic path utilizing cellulase as catalyst. Journal of the American Chemical Society 113:3079-3084.

Kolpak, F.J. and Blackwell, J. (1976) Determination of structure of cellulose ii. Macromolecules 9:273-278.

Ojeda, R., de Paz, J.L., Barrientos, A.G., Martin-Lomas, M. and Penades, S. (2007) Preparation of multifunctional glyconanoparticles as a platform for potential carbohydrate-based anticancer vaccines. Carbohydrate Research 342:448-459.

Qazi, S.J.S., Rennie, A.R., Cockcroft, J.K. and Vickers, M. (2009) Use of wide-angle x-ray diffraction to measure shape and size of dispersed colloidal particles. Journal of Colloid and Interface Science 338:105-110.

Sugiyama, J., Vuong, R. and Chanzy, H. (1991) Electron-diffraction study on the 2 crystalline phases occurring in native cellulose from an algal cell-wall. Macromolecules 
24:4168-4175.

Wang, N., Ding, E. and Cheng, R.S. (2008) Preparation and liquid crystalline properties of spherical cellulose nanocrystals. Langmuir 24:5-8.

Wang, N., Ding, E.Y. and Cheng, R.S. (2007) Thermal degradation behaviors of spherical cellulose nanocrystals with sulfate groups. Polymer 48:3486-3493.

Wang, S.H., Sato, S. and Kimura, K. (2003) Preparation of hexagonal-close-packed colloidal crystals of hydrophilic monodisperse gold nanoparticles in bulk aqueous solution. Chemistry of Materials 15:2445-2448.

Woodcock, C. and Sarko, A. (1980) Packing analysis of carbohydrates and polysaccharides.11. Molecular and crystal-structure of native ramie cellulose. Macromolecules 13:1183-1187. 


\section{Figure Legend}

Figure 1. Preparation of cellulose chains self-assembled on the surface of gold nanoparticles, CELL2Au, CELL13Au, and CELL41Au.

Figure 2. FT-IR spectra of (a) CTA13Au and (b) CELL13Au.

Figure 3. TEM images and size distributions of (a) (d) CELL2Au, (b) (e) CELL13Au, and (c) (f) CELL41Au.

Figure 4. Wide angle X-ray diffractgrams of (a) CELL13Au, (b) CELL41Au, and (c) cellulose II.

Figure 5. UV-vis spectra of (a) CELL2Au and (b) CELL13Au in water $(0.1 \mathrm{mg} / \mathrm{ml})$, and images of (c) CELL2Au, (d) CELL13Au, and (e) CELL41Au in water.

Figure 6. Intensity size distributions of (a) CELL2Au and (b) CELL13Au, and number size distributions of (c) CELL2Au and (d) CELL13Au, in water $(1.0 \mathrm{mg} / \mathrm{ml})$.

Figure 7. ${ }^{1} \mathrm{H}-\mathrm{NMR}$ spectra of (a) CELL13Au and (b) cellohexaose in deuterium oxide $\left(\mathrm{D}_{2} \mathrm{O}\right)$.

Table 1. Characteristics of CTAAu and CELLAu nanoparticles. 


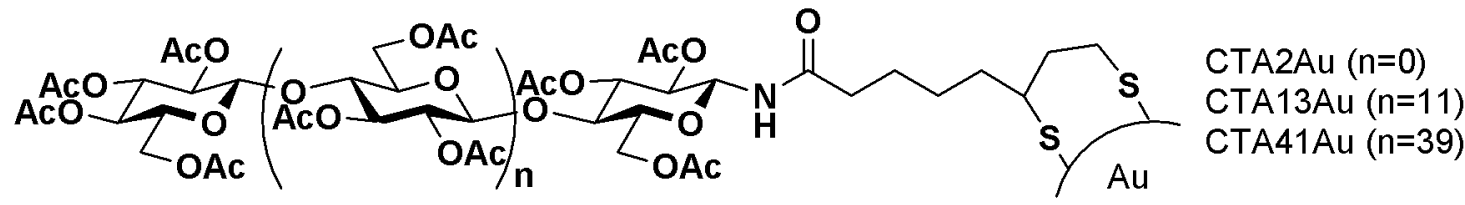

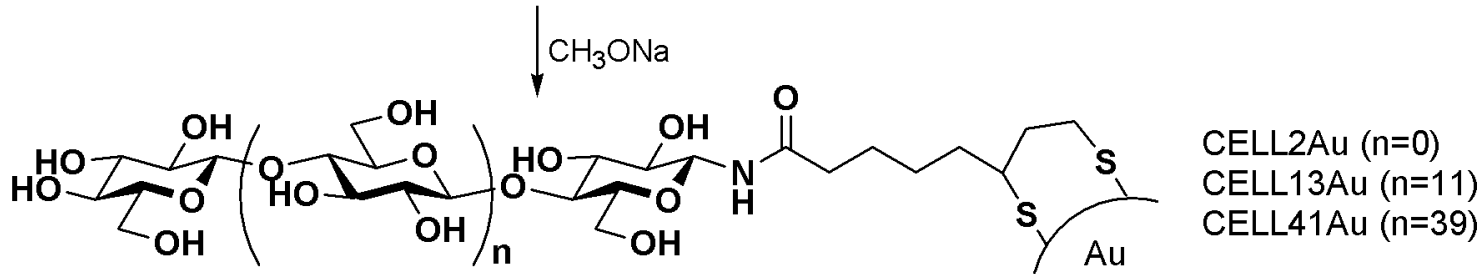

Figure 1 Preparation of cellulose chains self-assembled on the surface of gold nanoparticles.

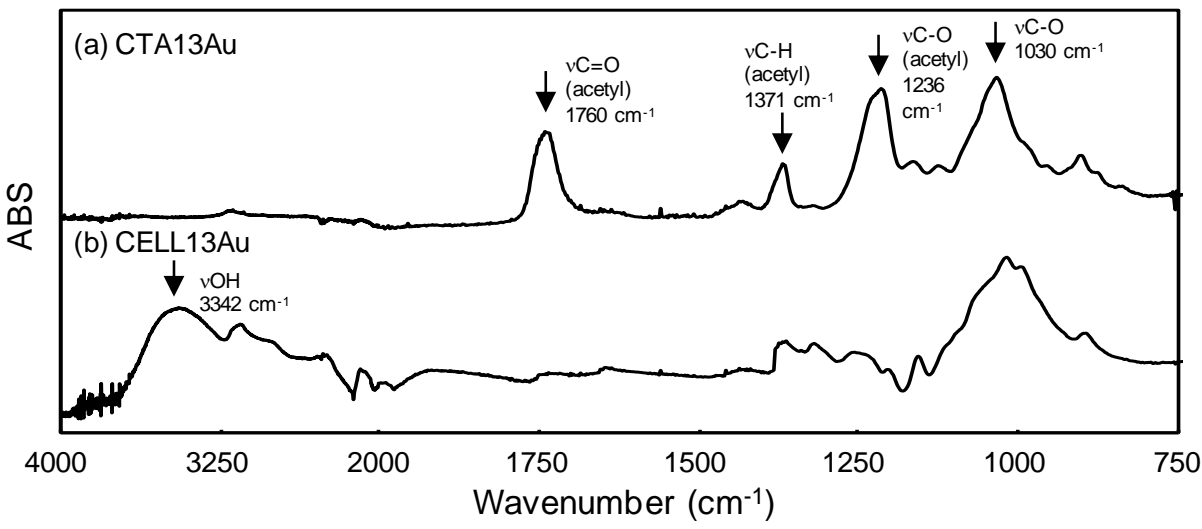

Figure 2. FT-IR spectra of (a) CTA13Au and (b) CELL13Au.
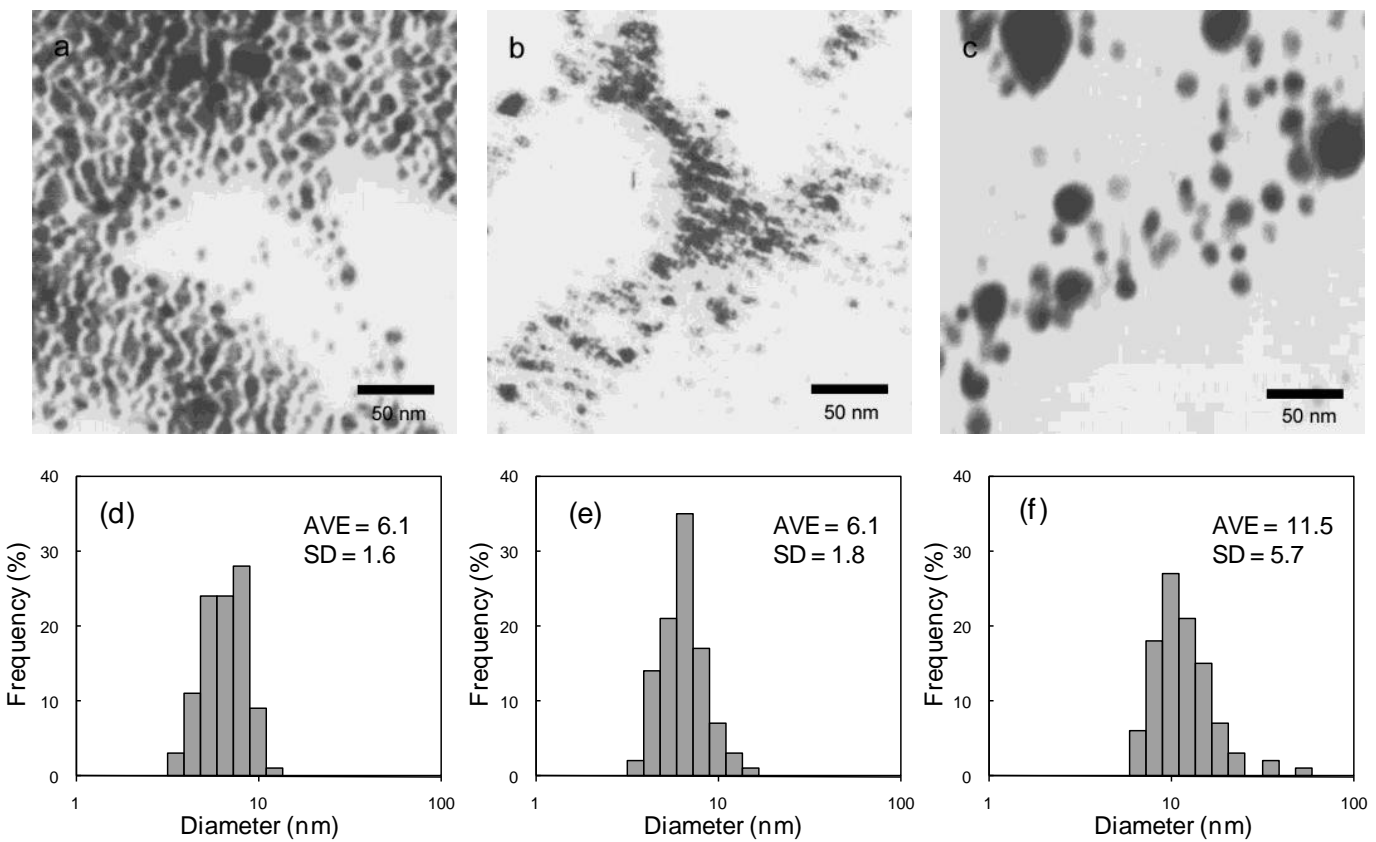

Figure 3. TEM images and size distributions of (a) (d) CELL2Au, (b) (e) CELL13Au, and (c) (f) CELL41 Au. 


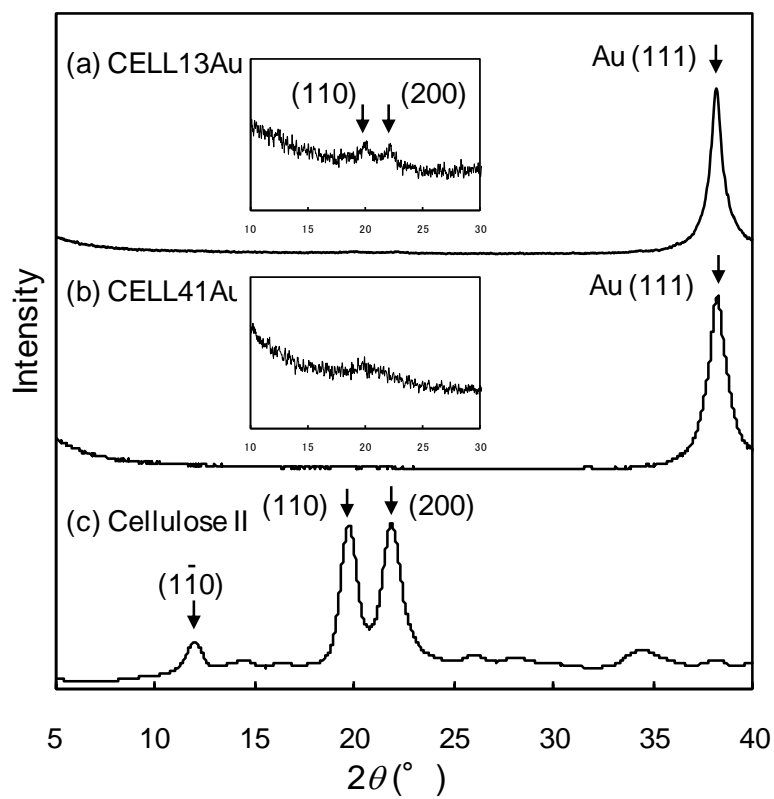

Figure 4. Wide angle X-ray diffractgrams of (a) CELL13 Au, (b) CELL41 Au, and (c) cellulose II.

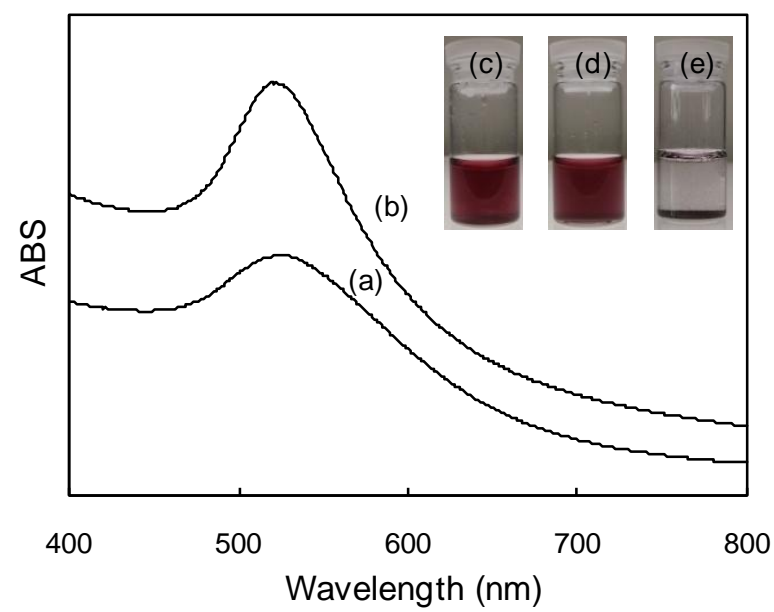

Figure 5. UV-vis spectra of (a) CELL2Au and (b) CELL13Au in water $(0.1 \mathrm{mg} / \mathrm{ml})$, and images of (c) CELL2Au, (d) CELL13Au, and (e) CELL41 Au in water. 

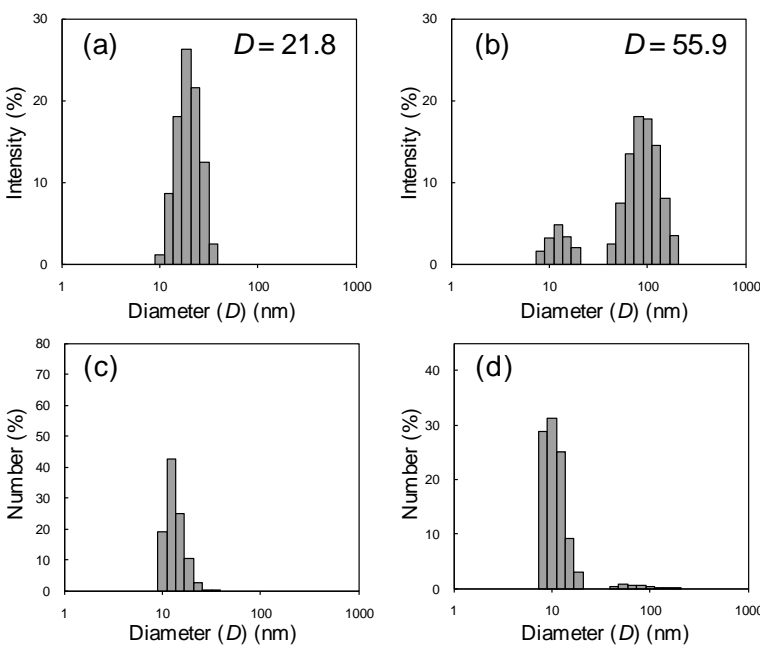

Figure 6. Intensity size distributions of (a) CELL2Au and (b) CELL13Au, and number size distributions of (c) CELL2Au and (d) CELL13Au, in water $(1.0 \mathrm{mg} / \mathrm{ml})$

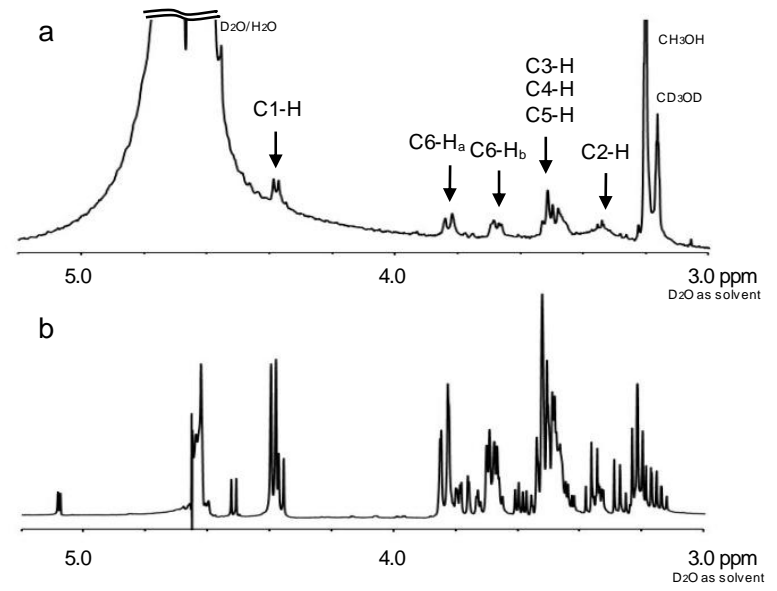

Figure 7. ${ }^{1} \mathrm{H}-\mathrm{NMR}$ spectra of (a) CELL13 Au and (b) cellohexaose in deuterium oxide $\left(\mathrm{D}_{2} \mathrm{O}\right)$.

Table 1. Characteristics of CTAAu and CELLAu nanoparticles.

\begin{tabular}{|c|c|c|c|c|c|c|c|}
\hline \multirow[t]{2}{*}{ Samples } & \multicolumn{2}{|c|}{$\begin{array}{l}\text { Diameter of Au core }(d) \\
(\mathrm{nm})^{a}\end{array}$} & \multirow{2}{*}{$\begin{array}{l}\text { Theoretical } \\
\text { length of } \\
\text { cellulosic chains } \\
(l)(\mathrm{nm})^{b}\end{array}$} & \multirow{2}{*}{$\begin{array}{l}\text { Composition of } \\
\text { cellulosic chains in } \\
\text { CT AAu and } \\
\text { CELLAu (wt } \%)^{c}\end{array}$} & \multirow{2}{*}{$\begin{array}{c}\text { Interchain } \\
\text { distance of } \\
\text { cellulosic chains } \\
(\AA)^{c}\end{array}$} & \multirow{2}{*}{$\begin{array}{c}\text { Calculated } \\
\text { diameter of } \\
\text { CT AAu and } \\
\text { CELLAu }\left(D_{\text {calc. }}\right) \\
(\mathrm{nm})^{d}\end{array}$} & \multirow{2}{*}{$\begin{array}{c}\text { Hydrodynamic } \\
\text { diameter of } \\
\text { CT AAu and } \\
\text { CELLAu }(D) \\
(\mathrm{nm})^{e}\end{array}$} \\
\hline & $\mathrm{AVE}$ & $\mathrm{SD}$ & & & & & \\
\hline CT A2Au & 8.7 & 1.4 & 2.0 & 15.7 & 5.1 & 12.7 & 16.6 \\
\hline $\mathrm{CT} A 13 \mathrm{Au}$ & 7.9 & 3.2 & 7.5 & 22.7 & 9.5 & 22.9 & 49.0 \\
\hline СТ A41 $\mathrm{Au}$ & 13.4 & 6.3 & 21.5 & 35.1 & 9.3 & 56.4 & 69.5 \\
\hline CELL2Au & 6.1 & 1.6 & 2.0 & 9.5 & 5.1 & 10.1 & 21.8 \\
\hline CELL13Au & 6.1 & 1.8 & 7.5 & 14.2 & 9.5 & 21.1 & 55.9 \\
\hline CELL41 Au & 11.5 & 5.7 & 21.5 & 23.3 & 9.3 & 54.5 & - \\
\hline
\end{tabular}

${ }^{a}$ Determined by TEM analysis. AVE: average, SD: standard deviation. ${ }^{b}$ Theoretical values of CT AS chain in streched conformation. The length of lipoyl chain in all-trans conformation $=1.0 \mathrm{~nm}$. ${ }^{c}$ Values of CELLAus were calculated from those of CT AAus determined in Ref (Enomoto-Rogers, et al. 2010). ${ }^{d} D_{\text {calc. }}=d+2 l .{ }^{e}$ Determined by DLS measurements. 


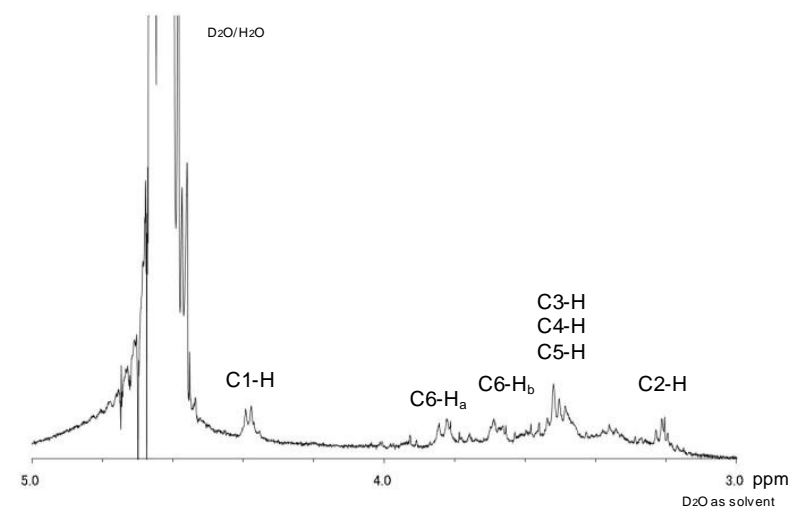

Figure S1. ${ }^{1} \mathrm{H}-\mathrm{NMR}$ spectrum of CELL13Au re-dissolved in water after freeze-dried. 